\title{
Can conditional cash transfer programs generate equality of opportunity in highly unequal societies? Evidence from Brazil
}

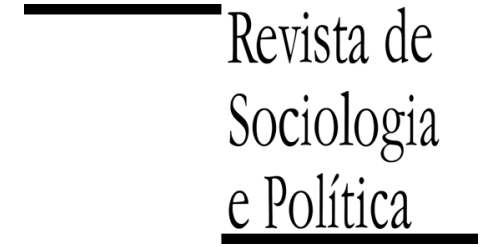

DOI 10.1590/1678-987314225107

\author{
Simone Bohn, Luciana Fernandes Veiga, Salete Da \\ Dalt, André Augusto Pereira Brandão, Victor Hugo de \\ Carvalho Gouvêa
}

\begin{abstract}
This article examines whether the state, through conditional cash transfer programs (CCT), can reduce the poverty and extremely poverty in societies marred by high levels of income concentration. We focus on one of the most unequal countries in the globe, Brazil, and analyze the extent to which this country's CCT program - Bolsa Família (BF, Family Grant) program - is able to improve the life chances of extremely poor beneficiaries, through the three major goals of PBF: First, to immediately end hunger; second, to create basic social rights related to healthcare and education; finally, considering also complementary policies, to integrate adults into the job market. The analysis relies on a quantitative survey with 4,000 beneficiaries and a qualitative survey comprised of in-depth interviews with 38 program's participants from all the regions of the country in 2008, it means that this study is about the five first years of the PBF. In order to answer the research questions, we ran four probit analyses related: a) the determinants of the realization of prenatal care; b) the determinants of food security among BF beneficiaries, c) the determinants that adult BF recipients will return to school, d) the determinants that a BF beneficiary will obtain a job. Important results from the study are: First, those who before their participation on PBF were at the margins have now been able to access healthcare services on a more regular basis. Thus, the women at the margins who were systematically excluded - black women, poorly educated and from the North - now, after their participation in the CCT program, have more access to prenatal care and can now count with more availability of public healthcare network. Second, before entering the Bolsa Família program, 50.3\% of the participants faced severe food insecurity. This number went down to $36.8 \%$ in very five years. Men are more likely than women; non-blacks more likely than blacks; and South and Centre-West residents more likely than Brazilians from other regions; to become food secure while participating in BF. Third, instead, that moment in 2008, a small proportion of the adult participants indeed were able to return to school and to increase their educational qualifications. The lack of technical skills and the huge predominance of informal employment are central social problems in Brazil and that the PBF has failed to address such issues. This study confirms what other previous studies have reported on: BF has had a positive impact in reducing poverty in the country. Hence the main contribution of the present study is in identifying the main determinants of unequal results among individuals participating in the BF program: why some, but not others, are more easily able to access the healthcare or to overcome food insecurity while in the program?
\end{abstract}

KEYWORDS: conditional cash transfer programs (CCT); family grant; food security; extremely poverty in Brazil; social rights in Brazil.

Recebido em 17 de Fevereiro de 2014. Aprovado em 30 de Março de 2014.

\section{Introduction}

In his renowned mid-twenty-century piece, T. H. Marshall compellingly argued that the existence of equality of opportunity is essential to the long-term survival of capitalist democracies (Marshall 1950). Without equality of opportunity, the formal legalistic civil and political equality embodied in the idea of citizenship in the long run can be perceived as meaningless and the political order risks losing its legitimacy. Marshall cautioned that the presence and full fruition of civil and political rights consecrated under a democratic regime do not imply the existence of socio-economic equality or that it will ever be created. On the contrary, under capitalism, which is quintessentially unequal, political 
and civil equality coexist, albeit uneasily, with socio-economic inequalities. According to Marshall, when the latter are extreme, this uneasy coexistence becomes highly conflictive, with the potential of destroying the social fabric. The struggle for social rights that generate and guarantee equality of opportunity, therefore, is presented as being crucial to attenuating substantive inequalities. The key element upholding a considerable degree of equality of opportunity, Marshall added, is universal access to the educational system, which enables individuals to gain entry into the job market and to attain their material independence and the conditions to fully realize their rights and autonomy.

What happens to highly unequal societies in which the virtuous cycle to which Marshall alludes does not exist or does not contemplate significant proportions of the population? Can the state act to ensure a less unequal playing field for those at the margins? This article examines whether the state, through a specific social policy called Conditional Cash Transfer programs (CCT), can reduce the poverty and extremely poverty in societies marred by high levels of income concentration.

This article focuses on one of the most unequal countries in the globe, Brazil, and analyzes the extent to which this country's CCT program - the worldly renowned Bolsa Família (BF, "family grant") program - is able to improve the life chances of extremely poor beneficiaries.

We seek to verify whether CCT policies have any impact on three important spheres of an individual's life (Cohen \& Franco 2006): the consumption, i.e., among other things, the attainment of food security; the inversion, which refers to access to the educational system and the acquisition of professional qualifications; and the production, which relates to the entry into the job market. For this, we take the three major goals of PBF (according to documents from the Ministry of Social Development) and check its successes and limitations: First, to immediately end hunger, with the direct transfer of cash to beneficiaries; second, to create basic social rights related to healthcare and education, by making school attendance for children and adolescents mandatory, for instance - has been designed with the intent of ending the intergenerational cycle of poverty. Finally, the program also has complementary and integrated policies, which aim at the integration of adults into the job market, so that the families can overcome their present situation of economic vulnerability.

We use a mixed method approach. The analysis relies on a quantitative survey with 4,000 beneficiaries and a qualitative survey comprised of in-depth interviews with thirty eight program's participants from all the regions of the country $^{1}$ in 2008 , it means that this study is about the five first years of the PBF. Whereas several studies of CCT programs utilize aggregate socioeconomic and demographic data to analyze the impact of these policies (Alvarez, Devoto \& Winters 2008; Lomeí 2008), this article uses individual-level data and is better positioned to capture the beneficiaries' description of the impact of the BF program on their lives before and after they joined the program.

The analysis is divided into six sections. The first one focuses on how intergenerational persistence diminishes the life chances of poor individuals. The second section briefly summarizes the basic features of CCT programs, their functioning and objectives. The third section focuses on the basic aspects of PBF in particular. The subsequent unit of the article center on information about method and data. Section five centers on whether BF helps children and adolescents of the poor and extremely poor have basic health care and it still focuses on the program's impact on the attainment of food security ${ }^{2}$; and section six examines the beneficiaries' success in entering the job market.
2 This article will not analyze the level of school attendance among the children of the Bolsa Família's participants. 
The quantitative survey did not have questions about this topic. Given that schools send the information on school attendance directly to the CCT program, some parents are unable to give precise information regarding their children's school attendance.
We conclude by showing that BF is very successful when it comes to helping individuals move up in the scale of food insecurity, i.e., to either overcome hunger or to face food scarcity less frequently. The results for educational and professional attainment and entry in the job market, indicate that the program improves the life chances of future generations much more than present ones and that there are significant racial, gender and regional gaps in the way this amelioration takes place.

Consequently the main contribution of the present study is in identifying the most important determinants of unequal results among individuals and families participating in the BF program Hence, we believe this study can make a good contribution to our understanding of the impact of $\mathrm{BF}$, and as a case study, it can help us understand the issues surrounding CCT programs in general.

\section{Life chances, intergenerational persistence and poverty}

${ }^{3}$ Among Bolsa Família's clientele there are individuals just marginally below the line of poverty as well as those who struggle daily to find food. There are not precise measurements of extreme poverty in the literature and we don't seek to create one in the scope of this article - even though we are aware of the presence of extreme poor families and individuals among the Bolsa Famíliabeneficiaries.

${ }^{4}$ There is a lot of controversy over where exactly the poverty line should fall or whether it should exist at all. See, among others, Oster, Lake and Oksman (1978), Sen (1999) and Vuollo et al. (2004).

${ }^{5}$ For an analysis on intergenerational persistence of income inequality, see Blandel et al. (2004).
According to the United Nations Development Programme's last major report on the topic, the proportion of people living on less than $\$ 1.25$ a day was reduced from $47 \%$ in 1990 to $22 \%$ in 2010 (UNDP 2013) ${ }^{3}$. Nevertheless, despite some progress, extreme poverty remains an alarming problem in the world's developing regions. Their most visible face is hunger. Without access to enough nutrients, individuals starve on a daily basis. Poor individuals are commonly identified as those lacking one or two dollars a day ${ }^{4}$. Nevertheless, poverty and especially extreme poverty are more than a monetary condition, i.e. the lack of financial resources needed to purchase food.

Recently, poverty, and extreme poverty in particular, began to be seen both as a specific material condition (or lack thereof) and as a distinct set of life chances as well. Extreme poverty decreases the likelihood that an individual, or specific groups within society, will have access to the educational system, be employed on a permanent basis throughout their lifetime and enjoy food security, physical and mental health. Extreme poverty is more than a transient condition; it hampers people's ability to attain individual autonomy on a more permanent basis (Despouy 1996). Furthermore, it tends to persist over time, i.e. to reproduce itself intergenerationally. Intergenerational persistence makes reference to the degree to which an individual's life is shaped by his or her parents' material and non-material conditions. Children of extremely poor parents tend to be undernourished and to drop out of school prematurely. As they lack formal education and professional skills, they tend to insert themselves in a precarious job market, usually devoid of social benefits and whose earnings are insufficient for the fulfillment of daily needs (Cohen \& Franco 2006, p. 2) . $^{5}$ Thus, extreme poverty, by locking up individuals or specific groups in the lowest educational and occupational strata of a social structure, severally undermines their ability to attain the autonomy needed in order for them to become masters of their own destinies. These individuals become stuck in a vicious circle, which renders them powerless and prevents them from enjoying the freedoms that are available to others.

More critical views of extreme poverty, thus, call attention to its more permanent features, which transcend merely gaining access to a steady supply of food. This perspective also emphasizes that not always do poverty and extreme poverty and their corollaries such as famines stem from natural calamities (Sen 1981). On the contrary, phenomena like these more commonly result not from a "crisis of provisions" (scarcity of goods), but from a "crisis of entitlement" (Dahrendorf 1988), which is a socially unequal structure of access to the goods and services available in a society. 
${ }^{6}$ Furthermore, in countries such as Brazil and Argentina, the expansion of social rights took place under a corporatist framework, i.e., social rights were extended to those who worked in the formal sector of the economy. Consequently, the rural poor in these countries never enjoyed the social rights that their countries' constitutions deemed to be universal. See Horowitz (1999).
In Latin America, according to some conservative estimates, $16.6 \%$ of the population, approximately 91 million individuals, lives below the line of poverty $-\$ 2$ dollars a day (World Bank 2009, p. 47). There are significant oscillations across countries and within them. Approximately $42.3 \%$ of the population are said to be poor in Nicaragua, whereas in Costa Rica it encompasses about $8 \%$ of the population (Economic Commission for Latin America and the Caribbean 2007). Furthermore, poverty and extreme poverty in rural areas tend to be higher than in the urban segments of most countries (Valdés 2000). In Brazil, for instance, the national level of poverty is around $32.7 \%$; but it varies between $14.4 \%$ in the state of São Paulo to $62.2 \%$ in the state of Alagoas; and there are considerable differences between the urban centers and the countryside.

In the last two decades poverty and hunger have been highly reduced, however in previous decades events in Latin America exacerbated the problems around the issue of poverty. The transition to democracy in the 1980s, in the midst of the so-called "third-wave of democratization" (Huntington 1991), fostered the expectation that, with the fall of the dictatorships, social rights would be increased throughout the region. Civilian governments would be able to address head-on the high levels of socioeconomic inequalities that for centuries have plagued the region. This expectation did not materialize. Some countries such as Brazil, but also Argentina, Bolivia, Peru, and Uruguay - experienced a dual transition. The change from authoritarianism to democratic regimes paralleled the dismantling of the developmental state, which for several decades had been the engine of economic growth in these societies. The stabilization and structural adjustment policies that some countries adopted have tended to reduce the state's offer of services when it comes to education, heath, and social security. However, most importantly for this region, it is the fact that these policies aimed at reducing the state's presence in the economy were implemented in societies that did not have a previous welfare state, founded upon Keynesian policies (Sposati 2002).

Quite the contrary, throughout the 1940s and 1970s, period in which these countries implemented the policies of import substitution industrialization, the states of the region were active in the areas of education, health and social security (Cohen \& Franco 2006, p. 5). However, the access to the social services provided by the state was far from being universal; in fact, it did not fully include the individuals at the very bottom of the social ladder ${ }^{6}$. The dictatorships that rose in reaction to the wave of progressive regimes in the 1960s and 1970s were for the most part founded upon pacts that were highly exclusionary politically, but that also did not involve significant advances in terms of social rights. Thus, when neoliberal policies become predominant in the region, they reached societies that lacked an enlarged social contract, deepening the tension between, on the one hand, the universal realization of citizenship rights, and, on the other, the decrease in the marked divisions between the poor and the non-poor (Sposati 2002, p. 7).

It is within this context of profound economic changes that some countries adopted a different approach to social policies. Instead of implementing social policies of universalistic scope, some countries chose to center the state's resources on the fight against poverty and extreme poverty, i.e. to implement socially targeted policies, among them the so-called conditional cash transfer programs.

\section{Conditional cash transfer programs}

In the 1990s governments from the Global South - some of them spurred on by international funding institutions - felt the need to devise new instruments of social policy in order to attenuate the negative social effects of the globalization 
and the structural adjustment processes, but in ways that would be compatible with the logic of market-based economies (Lomelí 2008, p. 2). As a consequence, this new model of social regulation emphasizes not labor rights, but human rights - among them universal access to healthcare, education and social security.

The conditional cash transfer programs emerged from the consensus that the intergenerational transmission of poverty stems from the lack of governmental investment in the formation of human capital in the areas of education, healthcare and nutrition and that the direct transfer of income to poor and extremely poor families and individuals could be a good way of overcoming this debility. According to the World Bank, as of 2009, twenty six countries of the world had active CCT programs (Fiszbein \& Schady 2009). Even though they have been more widely disseminated throughout Latin America and the Caribbean, where they have become important social policies, they have also been adopted in other parts of the world, such as Sub-Saharan Africa, South-East Asia, and the Middle East (Adatp \& Basett 2009). Currently, CCT programs have been implemented in 17 of the 20 Latin American countries. This type of program has not been adopted in Cuba and Haiti, and it was deactivated in Nicaragua (Gonnet 2012).

The CCT programs around the world share a whole host of similarities. They target the poor and extremely poor population and seek to attenuate the effects of hardship on the key phases of an individual's life. Hence, they focus on the nutrition of pregnant and nursing women; the nourishment and immunization of young children; and the education of children and adolescents. They present variations when it comes to the selection of beneficiaries and the functioning of the program. By and large, in a first stage, the central government selects the cities or municipalities which will receive the resources from this public policy. In order to be selected, municipalities have to be able to offer healthcare and educational public services and especially to be able to respond to the growth in demand that the CCT programs generate. In the sequence, programs select families within the municipalities and the selection criteria also vary. To be part of the Bolsa Família a low per-capita income is the key deciding factor. The Chilean counterpart, the CCT Chile Solidário, in contrast, selects extremely poor families that also have adults over 65 years old residing with the family (Soares et al., 2007). In some cases, the central government selects the beneficiaries directly and transfers the resources to subnational governments to administer the program; in others, the central government transfers

${ }^{7}$ Sewall (2008) argues that measures such as the direct distribution of resources from the central government to the recipient can reduce clientelism. Nevertheless, she cautions that central governments can profit electorally from these policies, when, they expand the program (e.g. either the amount of money that participants receive or the sheer number of beneficiaries) right before the elections. both the resources and the selection process to subnational administrations ${ }^{7}$.

Central to these programs is the notion that beneficiaries receive financial resources on condition that they perform certain activities related to healthcare and education. There is also variation across countries in reference to the fulfillment of these conditionalities. The Bolsa Família in Brazil, for instance, demands that the program's participants meet their obligations related to both healthcare and education in order to continue receiving the program's resources. In Mexico's Oportunidades and Nicaragua's Red de Protección Social da Nicarágua (now, deactivated), on the other hand, the social policies are subdivided into totally separate programs. Beneficiaries that meet the health conditionalities can continue to receive the health benefit, regardless of their performance in the educational realm and vice-versa (Lomelí 2008, p. 8).

These CCT programs are predicated on the premise that they can create a positive balance in the cost-benefit analysis that participants and other actors undertake (Brain \& Chudnovsky 2005). First, these policies are successful when the beneficiaries deem that the cost of fulfilling the conditionalities is lower than the financial benefits offered by the central or subnational govern- 
${ }^{8}$ Menezes Filho and Landim Jr. (2009, p. A9) show that in 2006 whereas the Bolsa Família program cost R\$7.5 billion, it generated an extra $\mathrm{R} \$ 12.6$ billion in taxes for municipalities. ment (Cohen and Franco 2006, p. 12). An important intervening factor in this cost-benefit analysis that participants undertake is the offer of services of health, education and nutrition made available by the state, which can enable beneficiaries to fulfill the conditionalities or prevent them from doing so. In other words, an essential ingredient to the success of conditional cash transfer policies is public investment in the areas of education, healthcare and social service, so that beneficiaries can meet their obligations. There is also a second cost-benefit analysis that is important to the success of the program. The cash benefit offered to participants has to be enough for individuals to overcome food insecurity and be able to improve their educational and professional skills. However, the benefit cannot be too high so as to de-stimulate the search for integration into the job market.

Governments and international financial and aid organizations also engage into a cost-benefit analysis. Governments have faced a several restriction on their fiscal capacity to undertake major investments in the social area and for them the CCTs are a way of doing a lot spending very little. The most expensive CCTs, the Brazilian Bolsa Família and the Mexican Opportunidades, for instance, cost less than 0.50 of the gross domestic product (Fiszbein \& Schady 2009, p. 5). As participants spent all the resources that they receive - mostly with the purchase of food (Rocha 2009) -, they stimulate the local economy, and therefore, generate taxes for governments. Thus, the CCT programs have been shown to cost less than their nominal cost might suggest ${ }^{8}$. The international organizations have also endorsed the CCTs, not only because these measures do not jeopardize fiscal discipline that they praise (and demand), but most importantly to change the perception that their previous interventions in Latin America and in the Global South in general have not had any impact on the alleviation of poverty (Soares et al. 2007, p. 10).

By and large, CCT programs have presented positive results when it comes to increasing children's and adolescents' school attendance; improving children's immunization record and the frequency with which babies, pregnant women, new mothers and nursing mothers access prenatal and postnatal care; and increasing food consumption among the poor (Behrman, Parker \& Todd 2009; Barham \& Malaluccio 2009; Adato \& Bassett 2009, p. 9). The predominant view is that the programs have been able to alleviate the most visible face of poverty, hunger and its health-related implications.

However, there have been some criticisms pertaining to CCT programs' effect beyond the consumption sphere, especially when it comes to their ability to improve the educational and professional skills of participants and their insertion into the job market. In the case of Mexico's CCT, Oportunidades, studies have shown that there has been little or no impact on the improvement of school learning, on children's cognitive development or on the level of employment among beneficiaries (Berhman, Parker \& Todd 2009, p. 464). Another limitation that plagues some CCT programs relates to governments' reduced capacity to effectively respond to the increase in demand for public healthcare and educational services that these policies generate, such as in the case of Nicaragua (Bradshaw \& Vazquez 2008).

We will briefly describe the structure of the CCT in Brazil.

\section{The Bolsa Família Program in Brazil}

The Bolsa Família is considered the largest conditional cash transfer program in Latin America and the Caribbean, with 11 million families among its participants from all the regions of the country. This CCT is the result of the amalgamation of previous programs. First, the PETI (Programa de 
Erradicação do Trabalho Infantil), which was a policy aimed at the eradication of child labor. Second, the Bolsa Escola (or School Grant), which gave cash to families in exchange for their children between 6 and 15 years to attend at least $85 \%$ of the school year. Third, the Bolsa Alimentação (or Food Grant), which forced participants to immunize their children and pregnant women to do prenatal and postnatal medical exams in exchange for the receipt of cash that could only be spent on the purchase of food (Soares et al., 2007, p. 10). The BF was created in 2003 in order to decrease the costs of disbursement of resources and to make it easier to verify whether the beneficiaries comply with the program's requirements.

There is considerable variation in the size of the benefits that each family receives under the Bolsa Família. Participants are selected among the poor, whose family monthly per capita income is up to R $\$ 140$ or US\$ 59 (February 2014 exchange rate); and the very poor, whose monthly family per capita income is less than R $\$ 70$ or US\$30. There are three types of cash transfers. First, the "basic benefit" of R $\$ 70$ (or US\$ 30) per month is given to extremely poor families, regardless of whether they have children and adolescents. Second, the "variable benefit" of R \$32 (or US\$14) per month, which is paid to families for each of their children and adolescents (between zero and 15 years of age) for a maximum of five children. Finally, there is the "variable benefit for adolescents", which covers families with youth between 16 and 17 years. In this case, families receive $\mathrm{R} \$ 38$ (US\$16) per month, for a maximum of two adolescents.

Bolsa Família's participants must fulfill a series of conditions in order to continue to receive the benefit. Children under six years must be immunized; pregnant women, babies and nursing mothers have to provide proof (through exams and records of doctor's visits) that they have undergone prenatal and postnatal medical care; and children and adolescents must attend school on a regular basis ( $85 \%$ and $75 \%$ of the time, respectively). The goal of the program is threefold. First, to immediately end hunger, with the direct transfer of cash to beneficiaries. Second, to create basic social rights related to healthcare and education. This system of conditions - making school attendance for children and adolescents mandatory, for instance - has been designed with the intent of ending the intergenerational cycle of poverty. Finally, the program also has complementary and integrated policies (such as non-compulsory educational programs for parents), which aim at the integration of adults into the job market, so that the families can overcome their present situation of economic vulnerability.

How successful has the program been in each of these goals? Primarily, we will center of attention on data and methods used.

\section{Data and methods}

We use a mixed method approach. The analysis relies on a quantitative survey with 4,000 beneficiaries and a qualitative survey comprised of in-depth interviews with thirty eight programmer's participants from all the regions of Brazil by Institute Datauff/UFF during 2008, it means that this study refers to the five first years of the PBF.

The data set reflects the results of interviews in all five regions of the country and in 53 municipalities. The goal was to develop a representative sample at each region of Brazil. There were five samples of 800 households, with $95 \%$ confidence level. The total sample for Brazil is accurate to $1.8 \%$. The qualitative research was conducted through in-depth interviews in 21 municipalities, keeping in mind the coverage of different regions and different size of the municipalities. 
It is important to note that numerous studies of the CCT programs present a serious limitation themselves. They base their analyses on aggregate macro-socioeconomic or demographic data, such as impact of these programs on the country's GINI coefficient (ibidem). Even though analyses based on these indicators are important and very revealing, they are deficient instruments, given that they are unable to overcome the issue of "ecological fallacy", which it is the problem of assuming that features that are common to the average or most of a collectivity also apply to each of its individual parts.

Nevertheless, more recently, CCTs have been evaluated using survey micro-data collected at the individual and household level (both nationally representative household surveys and purpose-designed surveys for impact evaluation). This article aims to contribute to overcoming this debility, by using individual-level data.

The goal is to understand whether the CCT program in Brazil, the Bolsa Família, has been able to address both the material and non-materials components of poverty.

\section{Consumption realm: health and nutrition}

This section will focus on three aspects: the impact of Bolsa Família on the level of children immunization and prenatal care, and also on food security, which are elements belonging to the consumption realm in an individual's life cycle. This article will not analyze the level of school attendance among the children of the Bolsa Familia's participants. The quantitative survey did not have questions about this topic. Given that schools send the information on school attendance directly to the CCT program, some parents are unable to give precise information regarding their children's school attendance.

It is important to mention that vaccination and prenatal care are conditions that beneficiaries must fulfill in order to remain in the program, whereas food security of the participants is one of the objectives of the CCT policy. Nevertheless, it is important to verify the extent to which beneficiaries comply with the conditionalities.

When it comes to children's vaccination, studies have shown that the CCT policies in general have had a positive impact on the immunization levels of infants and children. Even though there is no consensus on what the minimum level of vaccination should be, most experts point out that in order to eradicate certain diseases it is desirable that at least $95 \%$ of the population be vaccinated (Barrett \& Hoel 2007). In this regard, the CCT program in Nicaragua, when it comes to vaccines such as BCG, has been reported to have increased the immunization levels from $85 \%$ to almost $95 \%$. Similarly, the Mexican Progresa (the predecessor of Oportunidades) is said to have increased the coverage of MCV and BCG by $3 \%$ - but the coverage was already high (above $90 \%$ ) prior to the start of the CCT program ${ }^{9}$.

In the case of the Brazilian CCT program, $98.5 \%$ of the beneficiaries that are part of the survey reported having an up-to-dated immunization card for their children prior to their entry into Bolsa Família. After their entrance into the program, $98.7 \%$ reported that they complied with this conditionality. It is difficult to gauge the impact of Bolsa Família on this wide vaccination coverage. First, even before its launch in 2003, the Brazilian population already had a high level of immunization. Second, CCT policies that existed prior to BF already imposed children's vaccination as a condition for families to remain in the program. Finally, the Brazilian federal government has for a very long time being extremely active in making vaccines widely available. Vaccines for babies and children are free in Brazil. The federal government makes massive annual vac-

${ }^{9}$ For the numbers on the Nicaraguan case and on the Mexican counterpart, see Barham and Maluccio (2009 p. 612). 
${ }^{10}$ Healthcare is free in Brazil. However, public healthcare by and large offers low-quality service. There is a scarcity of health facilities; the existing public hospitals are always overcrowded and understaffed. Thus, middle class and more affluent Brazilians resort to private health care, which gives them access to the best hospitals and services. cination campaigns, and divulges them in all the mass media. Moreover, there is practically universal coverage in all the Brazilian territory even in the most isolated rural areas, where either vaccines are taken to individual households or health agents escort children and parents to nearby immunization centers, as the beneficiaries' testimony attest:

"I have always taken my children to the vaccination clinics. Even when my oldest son was small, whenever there was a vaccination campaign, I would take my children to be immunized". (Beneficiary, from Pien, Paraná, Southern Region).

"Since my children were little babies, they would always take vaccines. I used to live on a farm. Personnel from the Navy would go there, help me carry my children to the [makeshift] vaccination clinic in the school to be vaccinated". (Beneficiary from Corumbá, Mato Grosso do Sul, Center-West Region).

Almost all the Bolsa Familia's beneficiaries, therefore, comply with the vaccination requirement. Only two out of the thirty eight households that were part of the in-depth interviews had children with an immunization card not up-to-date. In one of the cases, the child was ill and would take the missing vaccine upon recovery; in the second case, the nearby health clinic had unexpectedly run out of yellow fever vaccine and the child was waiting to be immunized.

With reference to prenatal care, which is another conditionality that participants have to meet, there has been a change in the behavior of women beneficiaries $^{10}$. After entering Bolsa Família and during the five first years of the program (2003-2008), 26.5\% of the women had pregnancies and $88.7 \%$ of them complied with this requirement. It is interesting to note that there has been a change in the profile of pregnant women who underwent prenatal monitoring.

Table 1 shows the probit results of the determinants of pregnant women doing prenatal care in Brazil both before and after they became beneficiaries in the CCT program. Only the parsimonious models are shown in all tables of this article. The independent variables shown in Table 1 were coded as follows: Age group: $1=16-24 ; 2=25-34 ; 3=35-44 ; 4=45-54 ; 5=55$ years or older; each race is coded as 1 and 0 otherwise; educational level: $1=$ illiterate; $2=$ did not finish primary school; 3 = finished primary school; 4 = finished middle school; $5=$ started but did not finish high school; $6=$ finished high school; $7=$ started but did not finish college; 8 = finished college; each region is coded as 1 and 0

Table 1 - Probit analysis of the determinants of the realization of prenatal care

\begin{tabular}{lcc}
\hline Independent variables & $\begin{array}{c}\text { Before participating } \\
\text { in BF }\end{array}$ & $\begin{array}{c}\text { After participating in } \\
\text { BF }\end{array}$ \\
\hline Age group & $-.3893 * * *(.0308)$ & $-.3250 * * *(.0839)$ \\
White & $.2627 *(.1272)$ & \\
Black & $.2030(.1269)$ & \\
Brown & $.2683 *(.1178)$ & \\
Educational level & $.2406 * * * .0260$ & \\
South & $.3377 * * *(.0925)$ & \\
North & $-.3570 * * *(.0777)$ & \\
Has children under the age of 6 & & $.2601 * *(.0862)$ \\
Constant & $-1.6087 * * *(.1746)$ & $2.1651 * * *(.2750)$ \\
Pseudo R2 & .1811 & .0946 \\
$\mathrm{~N}$ & 3671 & 1012 \\
\hline
\end{tabular}

Standard errors in parentheses; *** $\mathrm{p}<.00 ; * * \mathrm{p}<.01 ; * \mathrm{p}<.05$

Source: The authors. 
11 There is a great regional disparity in Brazil. The South presents high levels of human development. The overpopulated cities of the Southeast present high levels of economic development, but also a considerable degree of urban poverty. The North and the Northeast have high levels of extreme poverty. Center-West has moderate levels of human development.

${ }^{12}$ In fact, most of the women who reported not having done prenatal care pointed to the lack of healthcare facility in their areas of residence as the key factor in the non-compliance. However, there is a clear generational aspect in the answer. Over one-third of the older women list this factor as the key obstacle, whereas only $1.2 \%$ of the younger women (between 16 and 24 years) mention this problem. otherwise. Before participating in the $\mathrm{BF}$, the key determinants for the realization of prenatal care were the woman's age group, educational level, race and the region of Brazil in which she resided. First, when it comes to age, younger women had a greater likelihood of fulfilling the requirement than older women. For instance, women of 25 to 34 years old had $4.8 \%$ greater chance of doing prenatal care than women between 35 and 44 years; and the same difference was visible between each consecutive age group. Second, the more educated the woman was, the higher the likelihood of her having done prenatal care. Third, white and brown women also tended to do prenatal care more often than black women. Region of residence was also an important factor ${ }^{11}$. The women beneficiaries from the South had a 3.6\% higher chance of doing prenatal care than their counterparts of the Southeast, who, in turn, had a 5.2\% higher likelihood of doing prenatal care than the participants of the North of Brazil.

When we focus on the behavior of pregnant women after their entrance into the Bolsa Família program, we notice that race, level of formal schooling and the region where the participant resides ceased to be statistically significant factors. Thus, before their participation in the CCT program, pregnant women who would not do prenatal care were predominantly black, illiterate or with very low level of formal schooling, and those who lived in the North region of country. After they became BF's recipients, age group was the only explanatory factor that retained its statistical significance. The younger the pregnant woman is, the greater the chance that she will do prenatal care. Younger women, thus, seem to have assimilated the idea that prenatal care is necessary and should always be done.

An important element in the explanation of this change in the profile is the accessibility of the healthcare. The universal right to healthcare in Brazil was introduced in the 1988 Constitution, i.e. over two and half decades ago. Since then, the Brazilian state has been actively supporting the expansion of the availability of medical care ${ }^{12}$. As a consequence, a large number of women that are 55 years or older had their children in a country undergoing a rapid process of economic modernization and urbanization, and in which the coverage of the public healthcare system was even more precarious than it is today. Some of the beneficiaries clearly make this point:

"I did prenatal care only for my youngest three children. For the others, I did not. I used to live in the countryside and there was only a pharmacy in the area, but approximately 20 kilometers away. There was no hospital or health clinic nearby; actually, I had my children at home". (Beneficiary, from Corumbá, Mato Grosso, Center-West Region).

Thus, over the last two and half decades, women who did not have access to prenatal care can now count with a greater availability of public healthcare network. The women at the margins who were systematically excluded - black women, poorly educated and from the North - now, after their participation in the CCT program, seem to have more access to the public healthcare system.

In order to gauge how the Brazilian CCT programme fares when it comes to the attainment of food security, we elaborated a scale of food insecurity. This scale will be used to assess a) the percentage of beneficiaries who improved their situation of food insecurity - i.e. overcame hunger altogether or faced food scarcity less often - and b) what factors explain any improvement. It is important to mention that even though this scale resembles the 'Brazilian Scale for the Measurement of Food Insecurity' (or EBIA) (Segall-Correa \& Salles-Costa 2008), especially the distinct levels of food insecurity, here we make use of slightly different questions. The scale of food insecurity used in this study does not address the food quality eaten, but only the amount of the same, therefore this aspect delimit the difference between EBIA scale and this one. In fact, our 
Table 2 - Percentage of participants in the scale of food insecurity after they entered BF

\begin{tabular}{lccccc}
\hline Point of departure (below) & Food security & $\begin{array}{c}\text { Low food } \\
\text { insecurity }\end{array}$ & $\begin{array}{c}\text { Moderate } \\
\text { insecurity }\end{array}$ & Severe insecurity & Total (N) \\
\hline Food security & $\mathbf{8 9 . 0 2}$ & 6.06 & 3.03 & 1.89 & $100 \%(264)$ \\
Low food insecurity & $\mathbf{1 8 . 6 8}$ & 61.57 & 16.14 & 3.61 & $100 \%(471)$ \\
Moderate food insecurity & $\mathbf{6 . 2 2}$ & $\mathbf{2 0 . 7 3}$ & 64.10 & 8.96 & $100 \%(1206)$ \\
Severe food insecurity & $\mathbf{3 . 5 2}$ & $\mathbf{7 . 3 9}$ & $\mathbf{2 2 . 4 4}$ & 66.65 & $100 \%(1961)$ \\
\hline
\end{tabular}

Pearson $\mathrm{Chi}^{2}(9)=3608.7397 \mathrm{Pr}=.0000$

Source: Adapted from Segall-Correa and Salles-Costa (2008). Calculations based on survey described on footnote 1.

survey lacks questions about food quality for both moments, before and after participants joined the CCT program so our statistical analysis centres on food quantity - and not food diversity.

Our scale classifies households into four categories (Table 2) and it is based on the magnitude of food accessed by an individual (i.e. quantity). First, there is the food security category, which comprises situations in which individuals or families face no serious dietary restrictions; there are no problems of the diet either, and food scarcity is not a major concern. Second, there is the category of low food insecurity, in which there is concern and uncertainty over the access to food in the near future. In this situation, usually adults face difficulties to maintain a balanced diet, i.e. there is a problem in the adults' diet. Third, the category of moderate food insecurity refers to situations in which there are severe quantitative restrictions in adults' diets. Finally, severe food insecurity comprises cases in which both adults and children face frequent food shortages; hunger is a likely occurrence in these cases.

We used these categories to classify the survey respondents and to verify whether they improved their situation after their admission into the programme. We used six questions to create the scale of food insecurity; one set of three questions refer to the period before the interviewee's participation into the CCT programme and one set refers to the period after the individual started to receive the benefit. As our survey lacks good questions about food quality for both before and after participants joined the programme, our statistical analysis centres primarily on food quantity - and not food diversity. The qualitative material, however, does enable us to make some considerations in regard to the programme's impact on the diet diversification. The questions from the quantitative survey that we employ are the following. First, 'Question 30. Before receiving the Bolsa Familia benefit, would your household lack food before you had money to buy more supplies?' whose answers are 'yes', 'no' and 'NS/NR'. Second, 'Question 32. Before receiving the Bolsa Família benefit, would somebody refrain from eating because there was not enough food for everyone?', whose answers are 'yes', 'no' and 'NS/NR (does not know or has not responded)'. Third, 'Question 39. Before receiving the Bolsa Família, how long would food last in your house?, whose answers are 'one week', '2 weeks', '3 weeks', '4 weeks (the whole month)' and 'NS/NR'. Questions 29, 31 and 38 have identical wording but refer to the period after the participant started to re-

${ }^{13}$ The scales varies from 0 to 3. The Appendix shows the questions and values assigned to each answer. ceive the $\mathrm{CCT}^{13}$. Table 2 displays the percentage of beneficiaries across levels of food insecurity before and after their admission into Bolsa Família.

Before being included in the Bolsa Família, 93.3\% of the participants included in the quantitative survey suffered from food insecurity: $12.1 \%$ faced low food insecurity; $30.9 \%$ suffered with moderate food insecurity; and a whopping proportion of $50.3 \%$ experienced severe food insecurity. After participating in the programme, food security became a reality that $12.0 \%$ of the 
beneficiaries enjoy; this represents almost double the original amount of $6.8 \%$. Among those still facing difficulties with food supply and quality, 18.0\% experience low food insecurity; $33.2 \%$ moderate; and $36.8 \%$ severe food insecurity. The latter category, thus, shrank about 13 percentage points. Thus, Bolsa Família is extremely associated to improvement of food security .

Given the low margin of error of our sample (less than 5\%), we can project what these numbers mean for the real population of 11.1 million participating households. A reduction of $13.4 \%$ in severe food insecurity indicates that approximately 1.5 million households or 6 million individuals (assuming an average family size of four) ceased to experience hunger on a daily basis. Similarly, an increase in 5.2\% in households attaining food security implies that the concern over access to food came to an end for approximately half a million households (or 2.3 million individuals). These numbers in themselves are extremely impressive and attest to Bolsa Família's great accomplishments.

Table 2 shows the changes across categories of food insecurity, i.e. the proportion of Bolsa Família beneficiaries who moved up or down in the scale, considering only the first five years of the program. For instance, out of all the beneficiaries who faced severe food insecurity before joining the programme, $33.4 \%$ improved their situation: $3.5 \%$ now enjoy food security; $7.4 \%$ have low food insecurity and $22.4 \%$ experience moderate levels of food insecurity. If we add all those beneficiaries who moved up the scale (i.e. those who do not face food insecurity anymore or experience it less frequently), the numbers show that about one-third of the sample improved their situation, which is quite a feat for social policies that cost so little, such as the CCT programmes. Once again, if we project this proportion to the universe of 11.1 families included in the Bolsa Família, we will conclude that through this CCT policy approximately 3 million families no longer face hunger on a daily basis, which is extraordinary.

On the other hand, approximately two-thirds of the participants in the programme remained in the same point of the scale of food insecurity that they were before receiving the family grant. What accounts for the Bolsa Familia's apparent difficult in moving more people up the scale, i.e., towards food security? First, it is the participants' level of extreme poverty. Table 2 shows that there is an association between the position that the participant was in the scale of food insecurity before becoming a beneficiary and their situation after their entry into Bolsa Família. Some numbers show the weight of this point of departure. For instance, it is easier for a family facing low food insecurity to attain food security after entering BF ( $18.7 \%$ of them did so), than for a family experiencing severe food insecurity (only $3.5 \%$ attained food security).

The profile of those participants who after receiving Bolsa Família started to enjoy food security is also an important element. Who are those beneficiaries? In order to answer this question, we ran a probit analysis using the attainment of food security after admission into the programme as the dependent variable (coded as 1 for the individuals that were in the food security category after receiving Bolsa Família and 0 otherwise). The explanatory factors include whether the individual is unemployed; for those who have a job, whether they work in the informal or formal sector of the economy; family per capita income; the time the participant has been a CCT beneficiary and whether he or she went back to school after joining the programme ${ }^{14}$. We expect that the following individuals will attain food security: those who are employed; those who work in the formal market; those with relatively high family per capita income and those who resumed their schooling after entering Bolsa Família. We also expect that the longer an individual has been receiving the family grant, the greater his or her likelihood of attaining food security.
14 These variables have been coded as follows: (a) unemployed $=1$ (zero, otherwise); (b) working in the informal sector $=1$ (zero, otherwise) and (c) beneficiary 
went back to school $=1$ (zero, otherwise).

15 The control group is composed by individuals of Asian and indigenous descent.

16 These variables have been coded as follows: (a) male $=1$ ${ }^{17} \mathrm{We}$ also show the probabilities calculated using the command 'dprobit' from STATA. Essentially, these numbers show the probabilities stemming from the discrete change in the dummy variable from 0 to 1 . Please note that, but for per capita income, all independent variables of the parsimonious model are dummies.
Table 3 - Probit analysis of the determinants of food security among BF beneficiaries

\begin{tabular}{lc}
\hline Independent variables & Probit coefficients \\
\hline Gender & $.2769 * *(.1278)$ \\
Black & $-.2585 * * *(.0758)$ \\
Per capita income & $.1587 * *(.0168)$ \\
South & $.2868 * *(.0821)$ \\
Center-West & $.2316 * *(.0848)$ \\
North & $-.2692 *(.0931)$ \\
Northeast & $-.3201 * *(.0983)$ \\
Constant & $-1.9348 * * *(.1060)$ \\
Pseudo R2 & .0812 \\
$\mathrm{~N}$ & 3717 \\
\hline
\end{tabular}

Standard errors in parentheses; *** $\mathrm{p}<.00 ; * * \mathrm{p}<.01 ; * \mathrm{p}<.05$

Source: The authors.

The control variables include gender; age group; three dummies for self-reported ethnic belonging (white, black or brown) ${ }^{15}$; whether the participant is married, is a homeowner, a housewife and has children under 6 years; the participant's level of formal schooling, income received from Bolsa Família, and his or her region of origin ${ }^{16}$. The results are presented on Table 3 , which displays both the full model and the parsimonious model ${ }^{17}$.

Several considerations emerge from the probit analysis. First, family per capita income is absolutely essential for participants to have no concern with the quantity or quality of their families' diet and their own. An increase of $\mathrm{R} \$ 20$ (or US\$ 8.51) in the beneficiary's per capita income augments in $2.8 \%$ the chances of him or her attaining food security.

Second, the data reveal a gender gap. After joining the CCT programme, male beneficiaries have a 5.7\% higher chance of enjoying food security than their female counterparts. The data indicate that, once a family accesses a slightly greater quantity of food, male adults are the first ones to eat better (after their children); mothers and adult females come last. Third, blacks also have difficulties to enjoy food security; they have a $4.1 \%$ lower chance of having enough food than any of the other racial groups. Afro-Brazilians, who have been traditionally at the bottom of social pyramid when it comes to other social indicators, have great difficulty attaining food security. Fourth, another interesting aspect, though, is the impact of the region of residence of the participants. Beneficiaries from the South and the Centre-West have a much higher chance$5.6 \%$ and $4.5 \%$, respectively - of attaining food security than those from the Southeast (the control group). Conversely, beneficiaries from the poorest regions of Brazil, the North and the Northeast present lower likelihoods $-4.3 \%$ and $5.0 \%$, respectively - of overcoming food insecurity than those from the control group.

The regional differences - highlighted by the statistical analysis - point out to the importance of the point of departure of each of the regions. In the South and Centre-West regions of Brazil, $70.4 \%$ and $64.8 \%$ of the participants, respectively, did not have food security before joining the programme. In the other regions, these numbers were much higher. Eight in every ten of the participants from the South-East (81.8\%) did not have food security before being admitted into the Bolsa Família. In the other two regions, the proportion was nine in every ten: $92.4 \%$ in the North-East and $90.5 \%$ in the North. Approximately one-third of the participants from the South and Centre-West enjoyed food se- 
curity before receiving the benefit: these were just marginally poor families, whose low income level qualified them for the programme, despite the fact that they did not have significant concerns over access to food or food diversity. Less than $10 \%$ of the participants from the North and Northeast had a similar profile. Thus, it is easier for CCT programmes to move beneficiaries out of the condition of food insecurity in areas with a lower contingent of extremely poor individuals and families (such as the South and Centre-West) than in regions where large proportions of the population experience extreme poverty (such as the North and Northeast). The testimony from two beneficiaries illustrates this point. Note that the first BF participant is from a poor area of the extremely impoverished Northeast; and the second beneficiary resides in the more economically dynamic South:

"Before [entering the BF program] we would eat much less. There was no bread, coffee; sometimes we lacked everything: rice, beans The lack of food was more intense for adults. Sometimes we would eat every other day. It was like that. Now we have pasta, beans; but at the moment my household lacks [cooking] gas". (Beneficiary from Raimundo Nonato, Piauí, Northeast Region).

\begin{abstract}
"We never lacked rice and beans; but with Bolsa Família we eat more food. Now we buy chicken, which we couldn't purchase before. Milk! I had never given milk to my children; now I buy it for them. Whatever [food items] the children ask for, now I can pretty much buy them". (Beneficiary from São Carlos, São Paulo, Southeast region).
\end{abstract}

These interventions from the beneficiaries point to at least two important intervening factors in the analysis of the degree of success of CCT programs. First, the clientele that they target is incredibly heterogeneous. In one extreme, there are extremely poor families and individuals for whom hunger is a daily occurrence; in the other, there are those who have concerns over food availability on the occasions when they cannot make ends meet. Second, this heterogeneity overlaps, albeit not perfectly, with significant regional inequalities. Because some regions carry a larger contingent of extreme poor families and individuals, the success of the CCT program in some areas will depend to a larger extent on other elements, such as the dynamism of the local and regional economies (more on this below).

A final important point is that poor families' level of food insecurity tends to very dynamic. Those enjoying food security can unexpectedly lack food and face hunger when they lose income, as when unemployment occurs or when the head of the household falls ill. Beneficiaries do not have financial resources stashed away for rainy days; neither do they enjoy labor rights to support them during moments of economic downturn.

All in all, our data show that Bolsa Família is clearly capable of enabling individuals and families to overcome food deprivation and to face food scarcity less often. However, it is much more difficult to rescue those facing severe concerns over access to food than those just marginally short of obtaining food security. The fact that Brazil has considerable pockets of extreme poverty makes it difficult for its CCT program to immediately lift all those families and individuals out of a condition of severe food insecurity.

Does Bolsa Família improve the adults' level of formal education, so as to improve their chances of securing a job in the market place? This is the topic of the next section.

\title{
VII. Inversion and production realms: adults' education and entry into the job market
}

So far we have examined elements of the Bolsa Família's program related to the well-being and development of the future generations (children's immuni- 
${ }^{18}$ Independent variables: (i) marital status (married $=1$; otherwise $=0$ ); (ii) if the respondent is a homeowner, unemployed, or a housewife, the value equals to 1 (otherwise = 0); (iii) income from Bolsa Família is the raw number in Brazilian Reals; (iv) if the beneficiary has children younger than six years $=1$ (otherwise $=0$ ); and $(v)$ the time the participant has been a CCT program beneficiary. zation and babies' prenatal care) and to the alleviation of the most visible hurdles that poverty entails: starvation and concerns over food availability. CCT policies also attempt at improving the situation of the current generation in ways that go beyond the important goal of attaining food security. The CCT program in Brazil supports complementary programs that focus on the improvement of the level of formal schooling for adults and on training for the job market. This section centers on the analysis of the Bolsa Familia's success in these two areas: a) sending adult beneficiaries back to school and b) helping them integrate into the job market.

First, when it comes to the enabling participants to improve their educational credentials, Bolsa Família's record is mixed. On the one hand, 53.3\% of the beneficiaries contemplated going back to school after starting to receive the CCT benefit. But only $14.9 \%$ did so. We ran a probit analysis of the determinants of going back to school and found that at least five elements are important in any attempt to improve the human capital of adult beneficiaries ${ }^{18}$. First, as Table 4 shows, the age of the participant is a significant factor: a beneficiary in the 16-24 age bracket has a $3.1 \%$ higher chance of going back to school than a participant in the 25-34 age group, and so on. Second, the previous educational level is also extremely important. The overwhelming majority of Bolsa Família beneficiaries have very little formal schooling: $7.5 \%$ of them are illiterate and $58.3 \%$ have not finished primary school. Individuals with a greater level of previous formal schooling have a higher chance of seeking to improve their educational background than those with little or no education. The in-depth qualitative interviews corroborate these numbers. This is the view of two beneficiaries with different educational and age profiles:

\footnotetext{
"When we get a little older, we realize how important education is to getting a job. I completed my first year of high school and now have just gone back to school; and that was even before being admitted into the Bolsa Família". (Beneficiary, from São Carlos, São Paulo, Southeast region).

"Yeah, I thought about going back to school. But when the person is older, there are so many problems with forgetfulness! So forget about it. I really would like to have studied when I was younger, when the person still has a whole future ahead of her. For an older person, that is not possible. Now it is my children's turn. They have studied. I do not want to study at this stage in my life". (Beneficiary from Maceió, Alagoas, Northeast region).
}

Table 4 - Probit analysis of the determinants that adult BF recipients will return to school

\begin{tabular}{lc}
\hline Independent variables & Probit coefficients \\
\hline Gender & $-.2734+(.1492)$ \\
Age group & $-.1342 * * *(.0282)$ \\
Homeowner & $.1141 *(.0568)$ \\
Educational level & $.0806 * *(.0187)$ \\
Time in BF & $.0450 *(.0199)$ \\
South & $-.1660 *(.0685)$ \\
Northeast & $-.2167 * *(.0738)$ \\
Constant & $-1.0401 * * *(.1307)$ \\
Pseudo R2 & .0278 \\
$\mathrm{~N}$ & 3368 \\
\hline
\end{tabular}

Standard errors in parentheses; ***p $<.00 ; * * \mathrm{p}<.01 ; * \mathrm{p}<.05 ;+\mathrm{p}<.06$ Source: The authors. 
${ }_{19}$ Most homeowners buy their houses without resorting to mortgages. Furthermore, poor families and individuals live in slums (where they have housing but have not necessarily purchased a home).
Younger participants and those with a certain level of education clearly see fewer costs and greater benefits in returning to school than those with a different profile. With a few more years at school, the former are able to, for instance, complete middle or high school, which can open up markets for them where there is the possibility of obtaining a formal job and some labor and social rights. Older individuals and those with an initial lower level of education, on the other hand, do not see the same cost-benefit relationship; for them, more years of schooling may seem to big an investment, especially given the fact that the market for these individuals is very limited and not in the formal sector of the economy. In the Table 4, as follows, we present a Probit analysis of the determinants that adult $\mathrm{BF}$ recipients will return to school.

The region of residence is an important factor. There is a greater tendency of participants from the Southeast (the control group) to go back to school than beneficiaries from other regions, such as those from the South and Northeast. These differences may be related to three other factors. First, the job market in the Southeast of Brazil is more competitive and, hence, demands greater level of formal education. Second, there is more availability of educational opportunities, such as schools and training programs sponsored by the private and public sectors. Third, there is also more availability of public daycares, which enables women to go back to school. In this last regard, the data show that women have a higher likelihood (of 5.5\%) than men of resuming their educational training (this difference is statistically significant at p. $<0.6$ level).

Time in the Bolsa Família's program is an important factor as well. Every additional year in the program increases in 1.05\% the chance that the beneficiary will go back to school. This result, along with the fact that homeowners have a higher tendency of seeking to improve their educational qualifications than those who do not own their homes, suggests that the return to school is more likely when participants attain a certain level of stability in life, i.e. when concerns with, for instance, paying a monthly rent are not present ${ }^{19}$. These two findings point to the need of integrated social policies. In other words, if the goal of CCT policies is to increase human capital among the adult participants in order to increase the autonomy and well-being of the current generations, then it is of utmost importance that supplementary programs aimed at fostering savings towards homeownership, for example, are also in place. On the other hand, the importance of the time in the program as a determinant, ceteris paribus, for participants to go back to school raises an important issue: for how long should each beneficiary stay in the program? Bolsa Família has been criticized in this regard, given that there are no clear timelines for beneficiaries to leave the CCT program (Draibe 2006). The program's current design establishes that families should "graduate" from the Bolsa Família (i.e. stop receiving the benefit) when they attain a certain level of stability and that the social agents monitoring the families are the ones responsible for deciding when that moment occurs. Even though a timeline for participants to leave the program might be desirable, our data indicate that this approach is somewhat correct. Myriad factors influence the beneficiaries' decision to seek their educational betterment, which renders a one-size-fits-all policy inadequate in this case.

How do Bolsa Família's beneficiaries fare in the job market? In this regard, descriptive statistics from our quantitative survey shows some signs of progress, albeit a modest one. First, between 2004 and 2007, the percentage of BF participants that were employed (who worked the whole year or most of the year) grew from $51.2 \%$ to $55.2 \%$. The proportion of unemployed beneficiaries went down from $47.1 \%$ to $43.5 \%$, which is still a high number. Second, there was also a growth in the proportion of beneficiaries with formal jobs. It went up from $9.8 \%$ in 2004 to $12.5 \%$ in 2007 . The last number is very revealing. It shows that out of the pool of beneficiaries with jobs in 2007 (2,155 participants 
of the quantitative survey), $77.3 \%$ of them worked in the informal market. The Bolsa Família's beneficiaries who are successful in finding work tend to overwhelming take up positions that are devoid of social rights, which are usually characterized by precarious working conditions and low wages. Thus, there is a close association between poverty and informal work. These are workers that have grown accustomed to working in the informal sectors of the economy (Sposati 2002, p. 8; Cohen \& Franco 2006, p. 7). When asked about their professional activities and occupation, these beneficiaries listed primarily daily cleaning (28.8\%), street vending (12.4\%), domestic work (6.6\%), "collection of recyclables" (4.4\%) and artisanship (4.4\%). "Collector of recyclables" refers to individuals who scavenge garbage dumping sites, dumpsters and even household trash for any recyclable items that they can gather and resell. "Daily cleaning people" are usually women; each day they go to a different household to clean it and are paid on a daily basis. Domestic workers are also as role women, who are employed by a single household. The latter may or may not be formally registered by their employers. On this regard, see Blofield (2009).

What are the determinants of a Bolsa Família beneficiary obtaining a job? We ran a probit analysis to search for these key explanatory factors between 2004 and 2007. The results are reported on Table 5, which only includes the most parsimonious models for each year. Each complete model had the following independent variables: gender, age group, marital status, three dummies for race (white, brown and black; others is the control group); whether the respondent is a homeowner, unemployed, or a housewife; his or her educational level, per capita family income, and income from Bolsa Família; four dummies for region (the Southeastern region is the control group); whether the beneficiary has

Table 5 - Probit analysis of the determinants that a BF beneficiary will obtain a job

\begin{tabular}{|c|c|c|c|c|}
\hline Independent variables & 2004 & 2005 & 2006 & 2007 \\
\hline Gender & $.5029 * * *(.1107)$ & $.4302 * * *(.1080)$ & $.4300 * * *(.1101)$ & $.3865 * *(.1111)$ \\
\hline Age group & & & $-.0423+(.0242)$ & $-.0500 *(.0245)$ \\
\hline Married & $-.1696 * * *(.0464)$ & $-.1621 * * *(.0455)$ & $-.1567 * *(.0464)$ & $-.2098 * * *(.0470)$ \\
\hline Black & $.1318 *(.0632)$ & $.1259 *(.0633)$ & $.0944(.0641)$ & $.1101+(.1358)$ \\
\hline Brown & $.1504 * *(.0515)$ & $.1657 * *(.0534)$ & $.1400 * *(.0539)$ & $.1358 *(.0551)$ \\
\hline Homeowner & & & $-.0917+(.0475)$ & $-.1849 * * *(.0487)$ \\
\hline Unemployed & $-.5211 * * *(.0573)$ & $-.6094 * * *(.0550)$ & $-.7705 * * *(.0560)$ & $-.9537 * * *(.0573)$ \\
\hline Housewife & $-.9757 * * *(.0560)$ & $-1.0746^{* * *}(.0542)$ & $-1.1932 * * *(.0548)$ & $-1.3433 * * *(.0553)$ \\
\hline Educational level & $.0237+(.0151)$ & $.0332 *(.0145)$ & $.0477 * *(.0154)$ & $.0422 * *(.0161)$ \\
\hline South & & $.0741(.0627)$ & $.1181+(.0630)$ & $.2398 * * *(.0633)$ \\
\hline Center-West & $.2575 * * *(.0589)$ & $.2486 * * *(.0612)$ & $.2328 * * *(.0621)$ & $.3902 * * *(.0633)$ \\
\hline North & & & & $.2331 * * *(.0633)$ \\
\hline Northeast & $-.2924 * * *(.0611)$ & $-.2479 * * *(.0618)$ & $-.2768 * * *(.0629)$ & \\
\hline $\begin{array}{l}\text { Has children under the } \\
\text { age of } 6\end{array}$ & $-.0664 * *(.0255)$ & $-.0726 * *(.0242)$ & $-.0848 * *(.0256)$ & $-.0536 *(.0259)$ \\
\hline $\begin{array}{l}\text { Took professional } \\
\text { training courses }\end{array}$ & & & & $.1143+(.0601)$ \\
\hline Constant & $.1103(.0986)$ & $.0248(.0807)$ & $.2826 *(.1261)$ & $.3012 *(.1268)$ \\
\hline Pseudo R2 & .1165 & .1349 & .1625 & .1944 \\
\hline $\mathrm{N}$ & 3717 & 3902 & 3897 & 3897 \\
\hline
\end{tabular}

Standard errors in parentheses; ***p $<.00 ; * * \mathrm{p}<.01 ; * \mathrm{p}<.05 ;+\mathrm{p}<.06$

Source: The authors. 
children younger than six years; the time the participant has been a CCT program beneficiary; and whether he or she attended professional training courses (coded as $1=$ yes and zero otherwise).

The data show some consistency over time in the profile of the beneficiaries who have been successful in getting a job. First, men have had a much higher probability of finding employment than women in all these years. This gender gap against women has decreased over time - it went from $19.5 \%$ in 2004, to $16.5 \%$ (2005), 15.6\% (2006) and 14.9\% in 2007 -, but it is still considerable. In order for the CCT programs to be successful in sending individuals back to the job market, complementary policies need to be in place, especially those related to the availability of daycares. Without those, women are still encumbered with a sexual division of domestic work that prevents them from being active participants in the market place. Simultaneously, because it does not generate income, domestic work remains undervalued or not valued at all (Teixeira 2008). In sum, these female beneficiaries who are mothers and have young children are confined to the position of homecare provider, which is a clear deterrent to their obtaining a paid position in the market place. Unless daycares become more available and/or there are more part-time positions or flexible working hours, the expectation of the CCT policy - that beneficiaries will integrate into the job market, obtain financial independence and leave the program - is structurally unrealistic in the case of this particular social group. Thus, for poor women in a certain phase of their adult life cycle (i.e. the married housewives with young children) equality of opportunity is non-existent. In the following Table 5 we look at the determinants that a BF's beneficiary will obtain a job.

Second, when it comes to the racial profile of the beneficiaries who obtain positions in the market place, blacks and browns are consistently more successful than the beneficiaries in the control group (those of Asian descent and the indigenous). At least two considerations are important here. First, it is important to understand that these results are not at all similar to those found in the Brazilian society as a whole. In the case of the latter, whites still present overwhelmingly higher rates of employment in all formal sectors of the economy than non-whites ${ }^{20}$. Second, the market in which blacks and browns are successful is the one described above: informal, which requires low educational level, little or no professional skills and pays very low wages.

Third, the results for the region dummies indicate that the success of the CCT programs in inserting beneficiaries in the market place is also dependent upon the dynamism of the local and regional economies. Between 2004 and 2006, the beneficiaries from the Center-West had systematically better chances of obtaining a job than those from the most dynamic region of the country, the Southeast. The opposite happened to the participants from the Northeast until 2006; the latter were always at a disadvantage in comparison to their Southeastern counterparts. These numbers are interesting because they uncover the Achilles' heel of the CCT programs. One of their key goals - that the adult beneficiaries obtain jobs - depends upon elements (such as the vitality of the local economies) that are ultimately beyond the control of social policies.

Fourth, the unemployed beneficiaries face an uphill battle. Those who are already employed seem to be able to meet the demands of the job market and, thus, have a higher chance of remaining employed. The likelihood of an unemployed participant finding work became progressively more negative over time. It went up from $-17.7 \%$ in 2004 to $-20.4 \%$ in 2005 ; $-24.8 \%$ in 2006 ; and $-29.9 \%$ in 2007. It remains to be seen whether these individuals form a permanent "industrial reserve army" or whether their increasingly lower chances of finding employment is associated with the economic cycle. 
Finally, even though the results show that the beneficiaries' tenure in the Bolsa Família program is not an explanatory factor of the success in entering the job market (this variable is absent from all the parsimonious models presented in the tables), it is interesting to note that in 2007 attending professional qualification courses became an important predictor of a successful employment search. Thus, factors associated with the inversion sphere - professional qualification of the beneficiaries - seem now to have become important springboards for them to land jobs.

All in all, the Bolsa Família beneficiaries did see their rate of unemployment decrease while in the program. It decreased in 4 percentage points. However, the rate of unemployment of 43.5\% amongst the program's participants in 2007 was still much higher than the rate for the Brazilian population as a whole, which was $9.3 \%$ on that year (Junior 2008).

\section{Conclusions}

Can CCT programs in general - and Bolsa Família, in particular - act to ensure a less unequal playing field for those at the margins in highly unequal societies?

This study with beneficiaries of the Bolsa Família program (BF) in Brazil confirms what other previous studies have reported on: $\mathrm{BF}$ has had a positive impact in reducing poverty in the country. Hence the main contribution of the present study is in identifying the main determinants of unequal results among individuals and families participating in the BF program: why some, but not others, are more easily able to access the healthcare or to overcome food insecurity while in the program? Important results from the study are:

First, those who before their participation on PBF were at the margins have now been able to access healthcare services on a more regular basis. Thus, the women at the margins who were systematically excluded - black women, poorly educated and from the North - now, after their participation in the CCT program, have more access to prenatal care and can now count with a greater availability of public healthcare network.

Second, before entering the Bolsa Família program, 50.3\% of the participants faced severe food insecurity. This number went down to $36.8 \%$ in very five years. Men are more likely than women; non-blacks more likely than blacks; and South and Centre-West residents more likely than Brazilians from other regions; to become food secure while participating in BF. Thus, there is no denying that the concern with the well-being of the future generations is being addressed.

Third, relevant statistic relates that there has been no reduction in adult employment among beneficiaries. This point should be emphasized, because a central critique of cash transfer programs is that they are a disincentive to work.

Instead, that moment in 2008, a small proportion of the adult participants indeed were able to return to school and to increase their educational qualifications. The lack of technical skills and the huge predominance of informal employment are central social problems in Brazil and that the PBF has failed to address such issues.

Ultimate, Bolsa Família has been successful in addressing the needs of the future generations with a view to breaking the intergenerational transmission of poverty, its results when it comes to the current generation are more mixed. Until 2008, Brazilian CCT programs represented an insufficient type of state intervention. 
Nevertheless, at present, in order to lift the adult participants out of poverty and to create a more level playing field for them, the national and local governments have being at the forefront; to be able to stimulate the local economies. Also, across the country, more particularly in the poorer regions, BFP beneficiaries have access to courses for professional training and receive more money as an incentive to take the course. In order poor adults, such as the woman below, are able to fulfill their most precious dream:

"I will enroll in a course on wall painting. I believe that with that course I will be able to try to get a construction job. The biggest dream of my life is to have a formal job before I am forty".

Simone Bohn (sbohn@yorku.ca) é Pós-Doutora em Ciência Política pela University of Chicago (EUA) e professora da York University (Canadá).

Luciana Fernandes Veiga (lucveiga@terra.com.br) é Pós-Doutora em Ciência Política pela University of California e professora de Ciência Política da Universidade Federal do Paraná (UFPR).

Salete Da Dalt (sdalt@uol.com.br) é doutora em Avaliação Política Social pela Universidade Federal Fluminense (UFF) e professora da mesma universidade.

André Augusto Pereira Brandão (aapbuff@globo.com) é doutor em Ciências Sociais pela Universidade do Estado do Rio de Janeiro (UERJ) e professor da Universidade Federal Fluminense (UFF).

Victor Hugo de Carvalho Gouvêa (datauff@ datauff.uff.br) é Doutor em Engenharia Estatística pela Université Pierre et Marie Curie (França) e professor da Universidade Federal Fluminense (UFF).

\section{References}

Adato, M.; Basett, L. 2009. Social Protection to Support Vulnerable Children and Families: The potential of cash transfers to protect education, health and nutrition. AIDS Care, 21(S1), pp. 60-75.

Alvarez, C.; Devoto, F.; Winters, P. 2008. Why do Beneficiaries Leave the Safety Net in Mexico? World Development, 36(4), pp. 641-656.

Barham, T.; Malaluccio, J. 2009. Eradicating Diseases: The effect of conditional cash transfers on vaccination coverage in rural Nicaragua. Journal of Health Economics, 28(3), pp. 611-621.

Barrett, S.; Hoel, M. 2007. Optimal Disease Eradication. Environment and Development Economics, 12(5), pp. $627-652$.

Behrman, J.; Parker, S.; Todd, P. 2009. Impacts of the Oportunidades Program: Schooling Impacts of Conditional Cash Transfers on Young Children: Evidence from Mexico. Economic Development and Cultural Change, 57(3), pp. 439-477.

Blandel, J.; Goodman, A.; Gregg, P.; Machin, S. 2004. Changes in Intergenerational Mobility in Britain. In: M. Corak, ed. Generational Income Inequality. Cambridge, UK: Cambridge University Press.

Blofield, M. 2009. Feudal Enclaves and Political Reforms: Domestic workers in Latin America. Latin American Research Review, 44(1), pp. 158-190.

Bradshaw, S.; Vazquez, A. 2008. Women Beneficiaries or Women Bearing the Cost? A gendered analysis of the Red de Protección Social in Nicaragua. Development and Change, 39(5), pp. 823-844.

Braun, M.; Chudnovsky, M. 2005. Transferencia condicionadas en efectivo como estrategias de reducción de la pobreza: un estudio comparativo in America Latina. Working Paper. Washington, D.C.: Interamerican Development Bank.

Cohen, E.; Franco, R. 2006. Transferencias con corresponsabilid una mirada latinoamericana. Mexico: FLACSO.

Dahrendorf, R. 1988. Revolutions of Modernity. In: The Modern Social Conflict. An essay on the politics of liberty. London: Weidenfeld \& Nicholson.

Draibe, S. 2006. Brasil Bolsa Escolar y Bolsa Familiar. In: E. Cohen; R. Franco, eds. Transferencias con corresponsabilid una mirada latinoamericana. Mexico: FLACSO.

Despouy, L. 1996. The Realization of Economic, Social and Cultural Rights. Final report on human rights and extreme poverty, economic and social council. Washington, D.C.: United Nations.

Fiszbein, A.; Schady, N. 2009. Conditional Cash Transfers: Reducing present and future poverty. Washington, D.C.: The World Bank.

Gonnet, C.O. 2012. The Role of International Organizations in a Policy Diffusion Process. Preliminary discussion about the Conditional Cash Transfer programs in Latin America. In: X Chilean Congress of Political Science. Santiago.

Horowitz, J. 1999. Populism and Its Legacy in Argentina. In: M. Conniff, ed. Populism in Latin America. Tuscaloosa: University of Alabama Press.

Huntington, S. 1991. The Third Wave of Democratization: Democratization in the Late Twentieth Century. Norman: University of Oklahoma Press. 
Junior, C. 2008. Desemprego fecha 2007 em 9.3\%, menor taxa desde 2002, diz IBGE. Folha Online, Jan 24. Available at: http://www1.folha.uol.com.br/folha/dinheiro/ult91u366485.shtml. Accessed Sep 92014.

2009. Desemprego é maior entre negros e pardos, afirma IBGE. Folha Online, May 13. Available at: http://www1.folha.uol.com.br/folha/dinheiro/ult91u565230.shtml. Accessed Sep 52014.

Lomelí, E.V. 2008. Conditional Cash Transfer as Social Police in Latin American: An assessment of their contributions and limitations. Annual Review of Sociology, 34, pp. 475-499.

Marshall, T.H. 1950. Citizenship, Social Class and Status. In:__. Citizenship, Social Class and Other Essays. Cambridge, UK: Cambridge University Press.

Menezes Filho, N.; Landim Jr., P.H. 2009. Expansão do Bolsa Família elevou PIB em 43,1 bilhões, aponta estudo. O Estado de S. Paulo, Oct 16.

Oster, S.; Lake, E.; Oksman, C. 1978. The Definition and Measurement of Poverty. Boulder: Westview Press.

Rocha, C. 2009. Developments in National Policies for Food and Nutrition Security in Brazil. Development Policy Review, 27(1), pp. 51-66.

Segall-Correa, A.M.; Salles-Costa, R. 2008. Novas Possibilidades de Alimentação a Caminho? Democracia Viva, 39, pp. 68-73.

Sen, A. 1981. Poverty and Famines: An essay on entitlement and deprivation. Oxford: Clarendon Press. 1999. Development as Freedom. New York: Anchor Books.

Sewall, R.G. 2008. Conditional Cash Transfer Programs in Latin America. SAIS Review, 28(2), pp. 175-187.

Soares, S.; Osorio, R.; Soares, F.; Medeiros, M.; Zepeta, E. 2007. Programas de Transferência Condicionada de Renda no Brasil, Chile e México: Impactos sobre a desigualdade. Working Paper N. 1 293. Brasília: IPEA.

Sposati, A. 2002. A profissionalização do agente institucional gestor da política social como política de direitos de cidadania: o caso da gestão da assistência social na cidade de São Paulo. In: X Congreso Internacional del CLAD sobre la Reforma del Estado y la Administración Pública. Santiago.

Teixeira, C.G. 2008. Análise do impacto do programa Bolsa Familia na oferta de trabalho dos homens e das mulheres. Working Paper. PNUD.

Valdés, A. 2000. A Rural Profile of Poverty in the Region. In: R. López; R. Valdés, eds. Rural Poverty in Latin America. London-New York: MacMillan-Saint Martin's Press.

Vuollo, R.; Barbeito, A.; Pautassi, L.; Rodríguez, C. 2004. La pobreza... de la política contra la pobreza. Buenos Aires: CIEPP.

\section{Other sources}

Economic Commission for Latin America and the Caribbean. 2007. Social Indicators and Statistics Database (BADEINSO). Santiago: Economic Commission for Latin America and the Caribbean.

UNDP. 2013. Human Development Report 2013. Millenium Development Goals: A compact among nations to end human poverty. New York: Oxford University Press.

World Bank. 2009. Global Economic Prospects. Commodities at the Crossroads. Washington: World Bank.

\section{RESUMO}

O artigo analisa se o Estado, por meio de programas de transferência condicional de renda (TCC), pode reduzir a pobreza e a extrema pobreza nas sociedades marcadas por elevados níveis de concentração de renda. Concentramo-nos em um dos países mais desiguais do mundo, o Brasil, analisando até que ponto os programas TCC desse país - como o Programa Bolsa Família (PBF) - são capazes de melhorar as oportunidades de vida dos beneficiários extremamente pobres, por meio de três principais objetivos do PBF: (i) para que cesse imediatamente a fome; (ii) a criação de direitos sociais básicos relacionados à saúde e à educação; (iii) por fim, considerando também as políticas complementares, para integrar adultos no mercado de trabalho. A análise baseia-se em uma pesquisa quantitativa com 4000 beneficiários e uma pesquisa qualitativa composta de entrevistas em profundidade com os participantes 38 do programa de todas as regiões do país, em 2008. O estudo refere-se aos cinco primeiros anos do PBF. Rodamos quatro análises PROBIT relacionadas (i) aos determinantes da realização do pré-natal; (ii) aos determinantes da segurança alimentar entre os beneficiários do BF; (iii) aos determinantes que os destinatários adultos do PBF vão retornar à escola e (iv) aos determinantes que um beneficiário PBF obterá um emprego. Importantes resultados do estudo são os seguintes: em primeiro lugar, aqueles que antes de sua participação no PBF estavam marginalizados foram capazes de acessar regularmente os serviços de saúde. Assim, as mulheres marginalizadas e sistematicamente excluídas - as negras, de baixa escolaridade e do Norte - agora, após a sua participação no programa CCT, têm mais acesso ao pré-natal e podem contar com mais disponibilidade de rede pública de saúde. Em segundo lugar, antes de entrar no programa Bolsa Família, 50,3\% dos participantes enfrentaram insegurança alimentar grave. Esse número caiu para $36,8 \%$ nos primeiros cinco anos do programa. Os homens são mais propensos do que as mulheres para obter a segurança alimentar ao participar do PBF; não-negros são mais prováveis do que os negros; moradores das regiões e Sul e Centro-Oeste são mais propensos do que os brasileiros de outras. Em terceiro lugar, em 2008 uma pequena proporção dos participantes adultos foi capaz de voltar para a escola e aumentar suas qualificações educacionais. A falta de competências técnicas e da enorme predominância do emprego informal são problemas sociais centrais no Brasil e que o PBF não conseguiu resolver. Este estudo confirma o que outros 
estudos anteriores relataram: o PBF teve um impacto positivo na redução da pobreza no país. Portanto, a principal contribuição do presente estudo está em identificar os principais determinantes dos resultados desiguais entre os indivíduos que participam do PBF: por que alguns, mas não outros, são mais facilmente capazes de acessar a cuidados de saúde ou de superar a insegurança alimentar, enquanto inseridos no programa?

PALAVRAS-CHAVE: programa de transferência condicionada de renda; Bolsa Família; segurança alimentar; extrema pobreza no Brasil; direitos sociais no Brasil. 


\section{Appendix}

Table 1 - Scale of Food Insecurity

\begin{tabular}{lcccc}
\hline Category & Questions 30 and 29 & Questions 32 and 31 & Questions 39 and 38 & Points in the scale \\
\hline Food security & 'no' $=0$ & 'no' $=0$ & '4 weeks' $=0$ & 0 \\
Low food insecurity & 'yes' $=1$ & $'$ 'no' $=0$ & '4 weeks' $=0$ & 1 \\
Moderate food insecurity & $' y e s '=1$ & $' y e s '=1$ & '4 weeks' $=0$ & 2 \\
Severe food insecurity & 'yes' $=1$ & 'yes' $=1$ & '1, 2 or 3 weeks' $=1$ & 3 \\
\hline
\end{tabular}

Source: The authors. 